\title{
The Legacies of European Colonization-World Trading System, Ecological Exchange and Mercantilism
}

\author{
Mingzhe Sun
}

Vanke Meisha Academy, Guangdong Province, People's republic of China jacksun2000@outlook.com

Abstract

This essay is about 3 legacies of European Colonialism around the world: the World Trading System and its influence of people around the world, the Ecological Exchange and its significance of agriculture and environment, and the Mercantilism which shape modern world politics and economics.

The World Trading System is established in the European colonization as a result of European involved in the trade in different regionally market. The Europeans explore and expand their trading network to every corner of the world, establish the colonies and connect them into the trading network. The wide spread colonies and trading networks shaped modern world. The trading network not only provides the chance of goods exchange, but also culture and idea exchange; the spread of religions, ideology and technologies was boosted by the trade activities.

The ecological exchange, introduces high yielded crops from America to old world, while also introduce old world species to the new continents. The corns and potatoes, which are the most representative new world crops, raised millions of people with their unbelievable moderation ability. The old world crops and animals adapted the new environment well and supported the whole world with their agriculture output. However, the invasive species and disease lead to massive destruction to the new world population and the ecological diversity; and caused the long term risk to the world.

At last, the mercantilism shaped the politic relations and economic connection of the European Maritime Empires and their colonies, and later expanded to all around the world. The mercantilism influenced the relationship of colonies with their mother countries before and after their independence. Despite of the international relationship, the mercantilism and the trade activity based on this theory shaped the world cultural, political and economical environment.

Keywords: Ecological Exchange, Legacies of European colonization, Mercantilism, World Trading System

\section{INTRODUCTION}

The political and economic configuration of the modern world has been shaped -- to a significant extent -- by the historical experience of European overseas expansion since the end of the fifteenth century. In the few centuries after 1492 when Columbus "discovered" what became known as the "Americas," numerous European powers developed "maritime empires" connecting enclave outposts and settlements around the world in a network of trade and cultural exchange that has left a powerful a powerful mark on the modern world. The Spanish, the Portuguese, the Dutch, the English and the French each developed their own distinctive traditions in these maritime empires, but the patterns of expansion, growth and eventual demise manifest many broadscale similarities as well as significant differences.

European colonial domination emerges, expands and eventual declines over the last five hundred years of world history. It turns to a growth of the industrial and financial empires of the nineteenth and twentieth century from the mercantile empires of 15 th through the 18th centuries. We should give attention to the motives and 
mechanisms of European expansion and on the other hand to the unconscious and unintended consequences of the global ecological, economic and political legacies that have emerged in the enduring aftermath of European colonial expansion.

Colonization of European nations from the 15th to the 20th centuries created a lasting impact on human history. What began as outward exploration and the quest to find a faster way to the east for wealth and goods eventually grew into larger patterns of economic and political control by European nations. The legacies of colonialism have formed important elements of modern societies and its lasting impacts include its influence on systems of world trade, an ecological exchange, and mercantilism.

Trade is a human activity that has occurred since the dawn of civilization. For centuries, people from different regions traded for goods such as extra crops, raw materials, and rare metals. During the golden age of classical civilizations, people traded luxuries such as spices and silk through elaborate trading networks, which linked civilizations across continents. One of the most influential trading networks in world history was the Indian Ocean trading system. In this network, large groups of civilizations scattered throughout Eurasia and Africa were involved. Using monsoon winds on the Indian Ocean as a stable power source, traders operated within a system of global exchange that impacted local peoples' daily lives. For example, as a result of this trading system, societies in the Middle East were able to used wood from African cities as materials for construction, Indian states were fed by crops from the Middle East, and African city states enjoyed tools and handiworks from India and the Middle East. In addition to introducing new resources to new areas in the trading network, international trading networks such as the Indian Ocean trade also was responsible for cultural exchange. For example, traders in Indian Ocean market represented diverse different culture backgrounds, from Jewish merchants in Eastern Africa to Islamic missionaries in South East Asia. In addition to the physical exchange of goods, this trading system supplied an environment in which traders of many backgrounds were able to share and spreads their belief systems along these routes. When European nations established colonies in these regions, they encountered diverse societies, which had a rich cultural knowledge of its trading partners.

Not all trading networks, such as the Indian Ocean trade, existed regionally. Other networks of trade, such as the Atlantic trading network, involved the exchange of goods across oceans. Advances in sailing technology, colonial demands for resources in the Americas, and the potential for exploiting the natural resources of the new world, led to the establishment of the Atlantic trading network. Since the creation of this trading network, additional trading routes between west coast of United States and Asia have been established. Today, the Indian Ocean market trade, Atlantic trading routes, and Trans-Pacific trade networks remain active and prosperous. Nearly six centuries since its initial conception, the Indian Ocean market remains as one of the most successful markets in the world, due in part to the discovery of oil resource in the Middle East. In this network, locations such as the Strait of Hormuz and the Strait of Malacca remain as the busiest sailing routes. For example, with a container volume of 24.12 million TEUS in 2018, Singapore, a nation within this trading network serves as one of the busiest ports in the world ("PSA Singapore" singaporepsa.com). Similarly, other figures, such as the Persian Gulf's daily oil flow of about 17 million bbl/d in 2011 (roughly 35\% of all seaborne traded oil and almost 20\% of oil traded worldwide) demonstrate that other regions, such as the Strait of Hormuz within the Indian Ocean trade, serve as a critical location for trade. ("Strait of Hormuz is chokepoint for $20 \%$ of world's oil" eia.gov).

In addition to the economic and commercial effects of the trading system, another influence of colonialism on world trading networks is the ecological exchange it brought. Before Columbus reached Americas and initiated large-scale colonization, there were very few domestic animals that could provide a stable source of food for a growing population. Although some examples, such as the Incas raising cuys exist, food sourced by domestic animals in North America was still limited. The introduction of pig and cow to North America produced a cascade of environmental, social, and cultural changes, which supported the growing population in the new world. Although the introduction of new domestic animals and high-yield crops facilitated a population explosion in colonies, the ecological changes brought on by u colonial powers also led to negative effects. The cultivation and sale of tobacco is one of the best examples of one such negative consequence. A long time export from the North American colonies, the wide proliferation of this crop into pipes and cigarettes has accounted for increased 
rates in lung and other kinds of cancers. In addition to its health toxicity, tobacco as a plant is an invasive species to the environment in which it was introduced. As the crop grew in popularity among farmers, it simultaneously competed with local species and damaged ecological diversity in the environment. Thus, colonialism does not just have an impact on the health of people, but also on the health of the environment.

A third consequence of global trade was the strengthening of mercantilism. Mercantilism is an economic theory whereby one nation controls trade over a region or people in order to accumulate wealth. This theory was heavily utilized between the $16^{\text {th }}$ and $18^{\text {th }}$ centuries by colonial powers such as Great Britain and France. Thousands of individuals in the Americas and Africa participated in colonial systems that oversaw the collection and processing of raw materials for the benefit of the colonial power. Through large scale trading networks, such as Atlantic trade, European nations with colonial holdings profited from the exportation of raw materials such as sugar, molasses, and tobacco from the colonies. While the European powers reaped profits from the sale of these raw materials, they dominated colonial markets by existing as the sole source of manufactured goods that colonies were barred from producing on their own. More complex systems of trade, such as Triangular trade, involved the transportation of labor, in addition to goods. In Triangular trade, African slaves were exchanged for guns, alcohol, horses, and other goods by Europeans. Slaves made their way across the Atlantic Ocean on the Middle Passage, where they were actioned off to landowners who forced them to work on plantations or farms to produce sugar, cotton, tobacco, or coffee. These products were then exported back to European nations to complete the final component of Triangular Trade. The threat of military force, an over-dependence on imported goods, and legal barriers stunted the economic and political growth of colonies. For example, the Sugar Act of 1764 and the Navigation Act of 1651 reduced opportunity for colonists to purchase imported goods from any nation other than Britain, thus minimizing an opportunity for a change in the way goods were traded and the potential for economic independence in the colonies. Because of colonialism and the economic systems, like mercantilism, which supported them, many colonies were not able to achieve independence until the $18^{\text {th }}$ or $19^{\text {th }}$ centuries. The influence of western culture and politics was therefore enlarged and changed the world politics environment forever

In conclusion, systems of world trade, ecological exchange, and mercantilism are just some of the many consequences of European colonialism in world history. Colonial powers, through economic, commercial, and political means shaped nations and global distributions of power. The impact of colonialism on the world did not just affect colonies at the time of their rule, but remains as lasting legacy that continues to shape the modern era.

\section{CONCLUSION}

Systems of world trade, ecological exchange, and mercantilism are just some of the many consequences of European colonialism in world history. Colonial powers, through economic, commercial, and political means shaped nations and global distributions of power. The impact of colonialism on the world did not just affect colonies at the time of their rule, but remains as lasting legacy that continues to shape the modern era.

\section{REFERENCES}

1. PSA Singapore, Sep. 2018 https://www.singaporepsa.com/

2. Strait of Hormuz is chokepoint for $20 \%$ of world's oil. U.S. Energy Information Administration, Sep. 5, 2012 https://www.eia.gov/todayinenergy/detail.php?id=7830

Citation: Mingzhe Sun. "The Legacies of European Colonization-World Trading System, Ecological Exchange and Mercantilism" American Research Journal of Humanities and Social Sciences, vol 4, no. 1, 2018, pp. 1-3.

Copyright (C) 2018 Mingzhe Sun, This is an open access article distributed under the Creative Commons Attribution License, which permits unrestricted use, distribution, and reproduction in any medium, provided the original work is properly cited. 